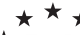

$\star$ Polityki Europejskie,

$\star$ Finanse i Marketing

$\star \star \star \quad 19(68) 2018$

Jacek Dziwulski

Politechnika Lubelska

\title{
Wpływ poziomu i jakości wiedzy pracowników na zarządzanie kapitałem ludzkim w organizacji usługowej na wybranym przykładzie
}

\author{
IMPACT OF THE LEVEL AND QUALITY OF EMPLOYEES' \\ KNOWLEDGE ON HUMAN CAPITAL MANAGEMENT IN \\ A SERVICE ORGANIZATION ON A SELECTED EXAMPLE
}

$W$ artykule przedstawiono wybrane koncepcje definiowania $i$ strukturalizacji wiedzy. Zidentyfikowano sktadowe kapitatu ludzkiego najbardziej istotne dla obszaru zarzqdzania wiedzq. Wskazano najistotniejsze elementy zarzqdzania organizacjami $w$ przyszłości, ze szczególnym uwzględnieniem zasobów niematerialnych.

Słowa kluczowe: pracownik wiedzy, zarzadzanie kapitałem ludzkim, organizacja usługowa.

\section{Wprowadzenie}

W XXI wieku wiedza stanowi najważniejszy element rozwoju gospodarki każdego kraju. Nadrzędną cechą gospodarki opartej na wiedzy jest nadanie priorytetowej roli wiedzy w procesie wzrostu gospodarczego. B. Mikuła twierdzi, że w gospodarce opartej na wiedzy ,zasadniczym źródłem wartości staje się wiedza, dlatego też organizacje chcące w tych warunkach odnosić sukcesy, muszą skoncentrować uwagę na procesach z udziałem wiedzy, a w szczególności jej pozyskiwania, tworzenia, transferu, ochrony, udostępniania i wykorzystania."1 Zatem gospodarka oparta na wiedzy wymusza na organizacjach konieczność dostosowania funkcjonujących modeli rozwiązań do zarządzania wiedzą w sposób efektywny i racjonalny. Wymaga to zastosowania odpowiednich metod i narzędzi zarządzania, co niejednokrotnie przejawia się w postaci dużych oporów wobec zmian wśród pracowników. Podejmowane w tej materii działania wyrażają się przede wszystkim w nacisku na ciąłe doskonalenie umiejętności, kompetencji teoretycznych i praktycznych posiadanych przez pracowników.

Oparcie gospodarki na wiedzy wymaga zmiany podejścia w organizacji przez pracowników do wykonywanych zadań i realizacji celów strategicznych. Istotna w tym zakresie jest również zmiana podejścia do zasobów przedsiębiorstwa, gdyż jak stwierdza L. Żabiński, w gospodarce opartej na wiedzy „,relatywne znaczenie takich czynników tradycyjnych, jak ziemia, praca i kapitał zmniejsza się, a rola wymienionego czwartego

1 Mikuła B., Organizacje oparte na wiedzy, Wydawnictwo Akademii Ekonomicznej w Krakowie, Kraków 2006, s. 11. 
czynnika rośnie.”² Odchodzenie od tradycyjnego postrzegania zasobów jest wymuszane przez zmiany organizacyjne oraz sposób myślenia o organizacji w kontekście osiągania założonych celów strategicznych oraz kształtowania nowych wyzwań.

A.L. Platonoff, S. Syska-Romańczuk i B. Moszoro wskazują na pewne kluczowe dla zrozumienia zagadnienia cechy gospodarki opartej na wiedzy, są to:

- wzrost gospodarki usług i inwestycje w aktywa niematerialne,

- potrzeba nowej technologii informacyjnej i łącznościowej oraz nowego społeczeństwa informacyjnego, nowe wymagania i podejście do wiedzy w uczących się organizacjach. ${ }^{3}$

\section{Metodyczne aspekty opracowania}

W ramach przeprowadzonych badań empirycznych przyjęto następujące założenia badawcze:

- celem badania jest pozyskanie opinii pracowników dotyczących wybranych elementów zarządzania kapitałem ludzkim w wybranym sklepie sieci Tesco Polska,

- problemem badawczym jest odpowiedź na pytanie, w jaki sposób pracownicy oceniają wybrane elementy zarządzania kapitałem ludzkim w wybranym sklepie sieci Tesco Polska,

- przedmiotem badania są wybrane elementy zarządzania kapitałem ludzkim w wybranym sklepie sieci Tesco Polska.

Założono następującą tezę badawczą że pracownicy w różny sposób oceniają wybrane elementy zarządzania kapitałem ludzkim w wybranym sklepie sieci Tesco Polska.

\section{Wiedza jako kluczowy zasób organizacji}

Wiedza stanowi jeden z najważniejszych elementów rozwoju współczesnych organizacji. Stanowi ona podstawę funkcjonowania zarówno organizacji produkcyjnych, jak i usługowych oraz handlowych. Wiedza jest głównym czynnikiem determinującym możliwości rozwoju społeczeństw i gospodarek. Przyjmuje się, że wiedza jest jednym $\mathrm{z}$ podstawowych zasobów przedsiębiorstwa. ${ }^{4} \mathrm{~W}$ dobie gospodarki opartej na konkurencyjności, wiedza nabiera szczególnego znaczenia w kontekście walki konkurencyjnej pomiędzy organizacjami prowadzacymi działalność o podobnym profilu.

Wiedza, którą dysponują organizacje składa się dwóch poziomów, tj. wiedzy jawnej oraz wiedzy ukrytej. ${ }^{5}$ Hierarchię wiedzy $\mathrm{w}$ oparciu o wskazany podział obrazuje rysunek 1.

2 Żabiński L., Marketing: koncepcje, badania, zarzadzanie, Akademia Ekonomiczna im. Karola Adamieckiego w Katowicach, Katowice 2002, s. 45 - 46.

${ }^{3}$ Mikuła B., Organizacje oparte na wiedzy, Wydawnictwo Akademii Ekonomicznej w Krakowie, Kraków 2006, s. 22.

${ }^{4}$ Kłak M., Zarzqdzanie wiedzq we współczesnym przedsiębiorstwie, Wydawnictwo Wyższej Szkoły Ekonomii i Prawa, Kielce 2010, s. 15.

${ }^{5}$ Brdulak J.J., Zarzqdzanie wiedzq a proces innowacji produktu. Budowanie przewagi konkurencyjnej firmy, Szkoła Główna Handlowa, Warszawa 2005, s. 14. 


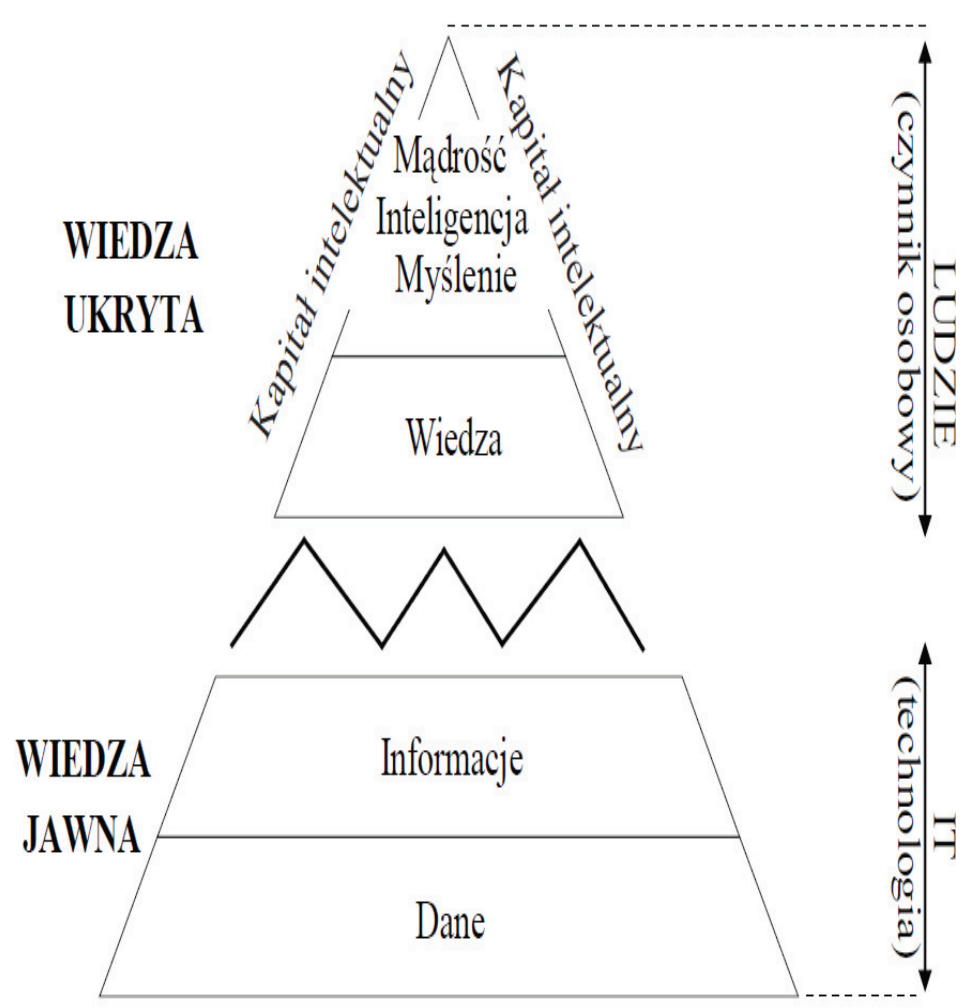

Rysunek 1. Hierarchia wiedzy w organizacji.

Źródło: Kłak M., Zarzqdzanie wiedzq we wspótczesnym przedsiębiorstwie, Wydawnictwo Wyższej Szkoły Ekonomii i Prawa, Kielce 2010, s. 15.

Na wiedzę jawną składają się dane oraz informacje. Dane to elementy składowe informacji, które reprezentowane są przez surowe i niepoddane analizie fakty, jak również liczby i zdarzenia. ${ }^{6}$ A informacje stanowią zbiór uporządkowanych danych. ${ }^{7}$

Wiedza jest pojęciem niezwykle szerokim i trudnym do jednoznacznego zdefiniowania. P. Drucker stwierdził, że wiedza to „efektywne wykorzystanie informacji w działaniu." ${ }^{\prime 8}$ A. Tiwana wiedzę określa jako „płynną mieszaninę kontekstowych doświadczeń, wartości, informacji i umiejętności tworzącą ramy dla oceny, rozumienia i przyswajania nowych doświadczeń i informacji." ${ }^{\text {"9 }}$ Ciekawy sposób zdefiniowania wie-

\footnotetext{
${ }^{6}$ Grudzewski W.M., Hejduk I.K., Zarzadzanie wiedzq w przedsiębiorstwach, Difin, Warszawa 2004, s. 75.

${ }^{7}$ Galata S., Strategiczne zarzadzanie organizacjami. Wiedza, intuicja, strategie, etyka, Difin, Warszawa 2004, s. 59.

${ }^{8}$ Drucker P, Spoleczeństwo prokapitalistyczne, Wydawnictwo Naukowe PWN, Warszawa 1999, s. 43.

${ }^{9}$ Tiwana A., Przewodnik po zarzadzaniu wiedzq. E-biznes i zastosowania CRM, Agencja Wydawnicza Placet, Warszawa 2003, s. 60 .
} 
dzy wprowadza E. Turban, który używa kategorii takich jak ,prawda przekonania, przewidywania, pomysły, osądy, oczekiwania, metodologię oraz know-how."

W literaturze przedmiotu istnieją również inne klasyfikacje, np. może być podział wiedzy na wiedzę organizacyjna, spersonalizowana, skodyfikowaną oraz ugruntowaną. ${ }^{11}$ Klasyfikację tą zaprezentowano na rysunku 2.

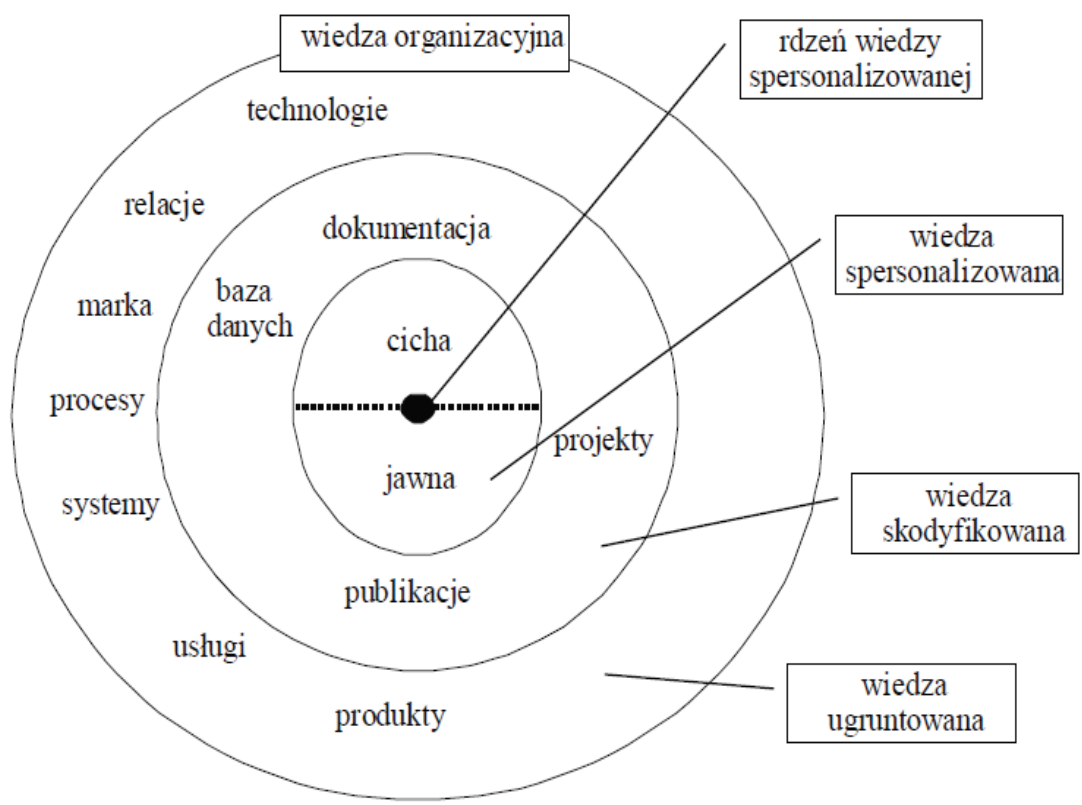

Rysunek 2. Główne kategorie wiedzy organizacyjnej.

Źródło: Perechuda K., Zarzadzanie wiedza w przedsiębiorstwie, Wydawnictwo Naukowe PWN, Warszawa 2005, s. 16.

W gospodarce opartej na wiedzy istotnym działaniem jest zwiększenie udziału usług oraz inwestycji w globalnej produkcji. Oznacza to zmianę proporcji pomiędzy produkcją oraz sektorem usług, na korzyść usług. Tradycyjna gospodarka opierała się głównie na produkcji, natomiast gospodarka oparta na wiedzy kierunkuje swoją uwagę przede wszystkim na zwiększenie udziału w zakresie usług oraz inwestycji. Ponadto rozwój gospodarki opartej na wiedzy wymusza rozwijanie nowych technologii informacyjnych, jak również i łącznościowych. To z kolei implikuje powstawanie społeczeństwa informacyjnego nowej generacji, o wyższym poziomie posiadanych umiejętności i kompetencji.

\footnotetext{
${ }^{10}$ Tiwana A., Przewodnik po zarzqdzaniu wiedzq. E-biznes i zastosowania CRM, Agencja Wydawnicza Placet, Warszawa 2003, s. 61.

${ }^{11}$ Perechuda K., Zarzqdzanie wiedzq w przedsiębiorstwie, Wydawnictwo Naukowe PWN, Warszawa 2005, s. 16.
} 
W literaturze przedmiotu wskazać można również inne podejście do wyodrębnienia cech gospodarki opartej na wiedzy. Wśród nich E. Skrzypek wymienia następujące cechy gospodarki opartej na wiedzy:

- gospodarka świadczeń, większość pracowników zatrudniona jest w sektorze usług,

- głównym potencjałem jest wiedza,

- gospodarka nadmiaru czy raczej nadmożliwości,

- bezpośrednio oparta na generowaniu, dystrybucji i zastosowaniu informacji i wiedzy,

- przeważająca większość firm opiera swoją przewagę konkurencyjną na wiedzy. ${ }^{12}$

Wyżej przedstawiona koncepcja opiera się na tym, że gospodarka oparta na wiedzy stanowi z jednej strony wyzwanie dla tradycyjnych organizacji, a $z$ drugiej strony szansę na rozwój, pozyskiwanie nowych klientów, a także uzyskanie korzystniejszej niż konkurenci rynkowi pozycji konkurencyjnej. Zarządzanie wiedzą w organizacji oznacza „wytworzenie w przedsiębiorstwie odpowiednich procedur i umiejętności ukierunkowanych na osiagnięcie celów jego działania dotyczących różnego rodzaju działan informacyjnych."’33 Jednocześnie należy stwierdzić, że zarządzanie wiedzą jest „procesem ciagłych realizacji funkcji zarządzania, skoncentrowanym na zasobach wiedzopochodnych (wewnętrznych i zewnętrznych, istniejących i nieistniejących, znanych i ukrytych) oraz zadaniach i instrumentach organizowania i komunikowania." ${ }^{\text {.14 }}$ Podstawowe aspekty zarządzania wiedzą w organizacji obrazuje rysunek 3 .

\footnotetext{
${ }^{12}$ Mikuła B., Organizacje oparte na wiedzy, Wydawnictwo Akademii Ekonomicznej w Krakowie, Kraków 2006, s. 22.

${ }^{13}$ Forlicz S., Informacja w biznesie, Polskie Wydawnictwo Ekonomiczne, Warszawa 2008, s. 39.

${ }^{14}$ Perechuda K., Zarzqdzanie wiedzq w przedsiębiorstwie, Wydawnictwo Naukowe PWN, Warszawa 2005, s. 219.
} 


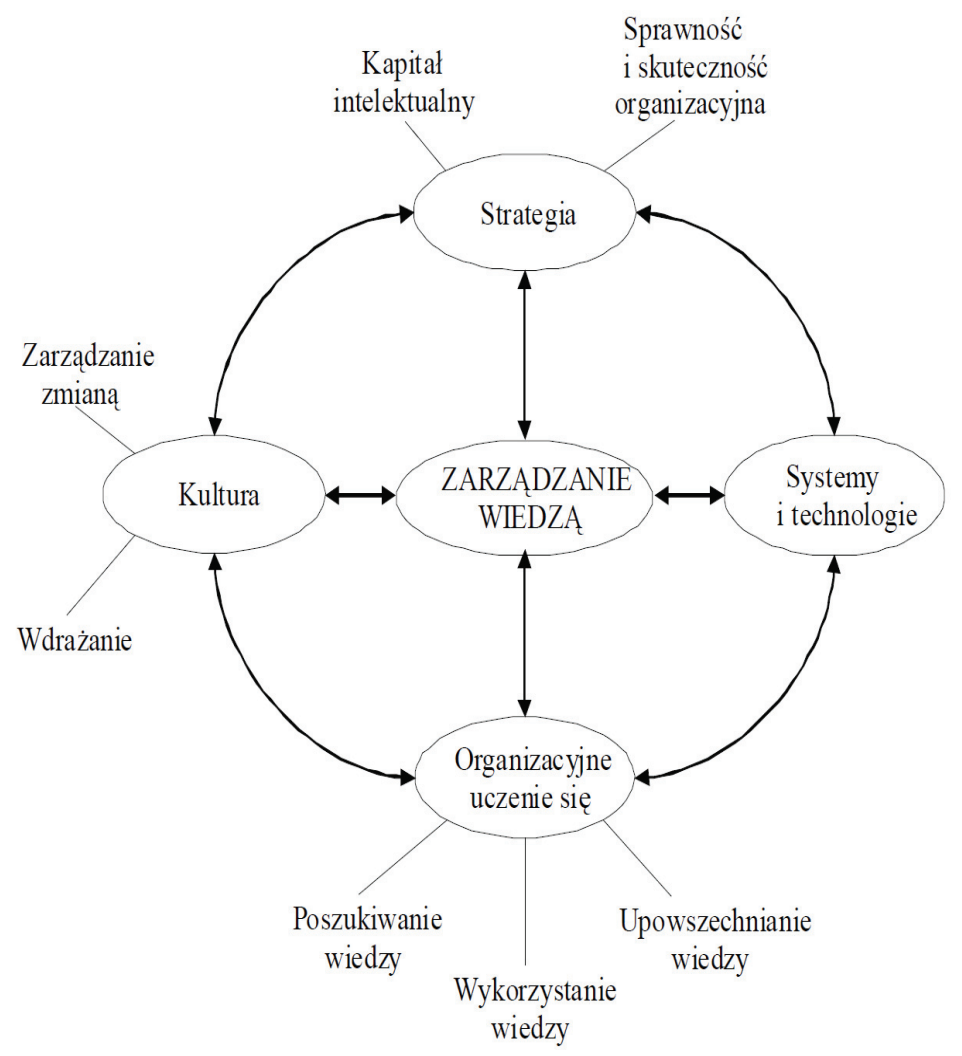

Rysunek 3. Główne kategorie wiedzy w organizacji.

Źródło: Jashapara A., Zarzqdzanie wiedza. Zintegrowane podejście, PWE, Warszawa 2006, s. 28.

Punktem wyjścia do zarządzania wiedzą w organizacji jest przyjęta strategia działania organizacji, w której powinny znaleźć się podstawowe kwestie odnoszące się do założeń zarządzania wiedzą. Strategia i wizja organizacji powinny odzwierciedlać możliwości przedsiębiorstwa w zakresie kapitału intelektualnego oraz sprawności i skuteczności organizacyjnej. W zarządzaniu wiedzą ważne jest także organizacyjne uczenie się, które odnosi się do poszukiwania wiedzy, jej wykorzystania i upowszechniania. Ponadto zarządzanie wiedza obejmuje systemy i technologię oraz kulturę organizacyjną odnoszącą się do zarządzania zmianą oraz wdrażania.

Proces zarządzania wiedzą jest wieloaspektowy i charakteryzuje się wieloma wzajemnymi elementami kształtującymi go. Schemat zarządzania wiedzą przedstawiono na rysunku 4. 


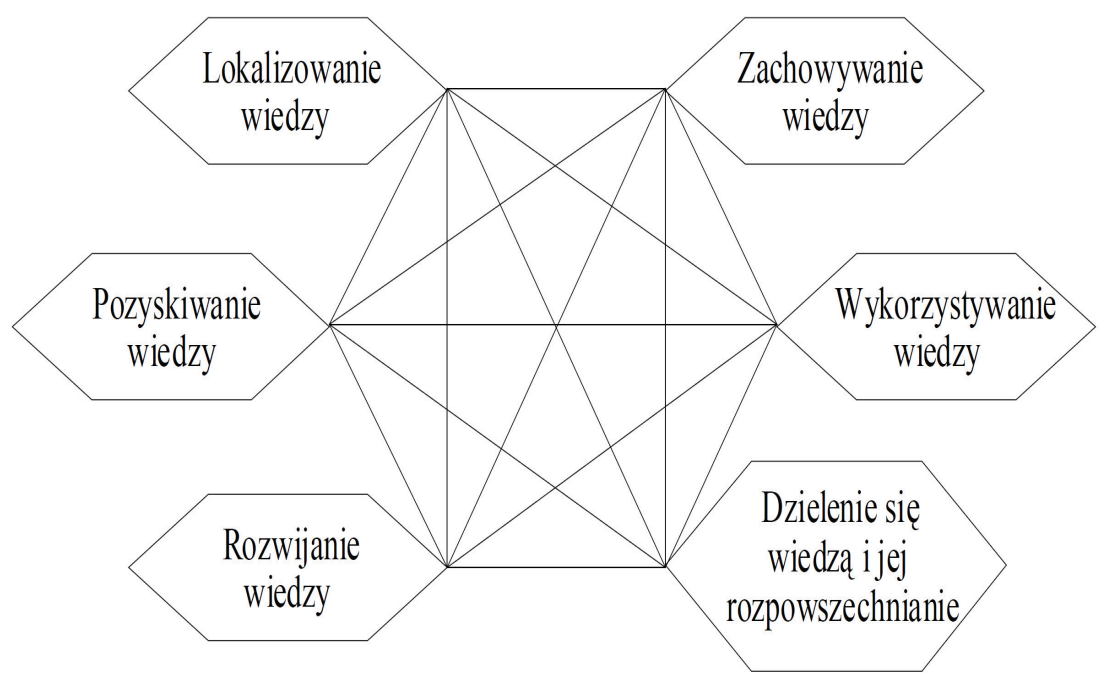

Rysunek 4. Schemat zarządzania wiedza.

Źródło: Probst G., Raub S., Romhardt K., Zarzqdzanie wiedzq w organizacji, Oficyna Ekonomiczna, Kraków 2002, s. 42.

Struktura procesu zarządzania wiedzą obejmuje przede wszystkim lokalizowanie wiedzy, pozyskiwanie wiedzy, rozwijanie wiedzy, dzielenie się wiedzą i jej rozpowszechnianie, wykorzystywanie wiedzy oraz jej zachowywanie. Każdy z elementów procesu powiązany jest z pozostałymi. Co oznacza, że jeden element wpływa na pozostałe i odwrotnie, pozostałe elementy wpływają na analizowany składnik procesu zarządzania wiedzą.

Zarządzanie wiedzą związane jest z powstawaniem różnego rodzaju barier, które należy pokonać celem kompleksowego wdrożenia rozwiązania. M. Żemigała wskazuje następujące bariery zarządzania wiedzą w przedsiębiorstwie:

- $\quad$ system zarządzania, który nie nagradza wysiłków pracowników w poszukiwaniu wiedzą i dzielenia się nią,

- $\quad$ niewystarczająca motywacja przełożonych do dzielenia się wiedzą,

- brak czasu na przekazywanie swojej wiedzy pozostałym,

- niewiedza pracowników, kto posiada poszukiwane przez nich informacje,

- struktura organizacyjna sprzyjająca jedynie wymianie informacji wewnątrz działów przedsiębiorstwa,

- $\quad$ kultura firmy promująca wyniki jednostki i jej wiedzę zamiast dzielenia się nią,

- ograniczone środki na wdrażanie nowych rozwiązań,

- nieprzyjazny system informatyczny,

- nieświadomość pracowników, że ich wiedza może się przydać innym. ${ }^{15}$

${ }^{15}$ Żemigała M., Jakość w systemie zarzadzania przedsiębiorstwem, Placet, Warszawa 2008, s. 168. 


\section{Analiza i ocena wybranych elementów kapitału ludzkiego na przy- kładzie organizacji usługowej}

W badaniu udział wzięło 50 pracowników sklepu Tesco Polska, którego siedziba mieści się w Stalowej Woli. Wśród respondentów przeważająca grupą były kobiety, które stanowiły $84 \%$ ogółu badanych (42 osoby). Udział mężczyzn w próbie badawczej wynosił 16\% (8 osób).

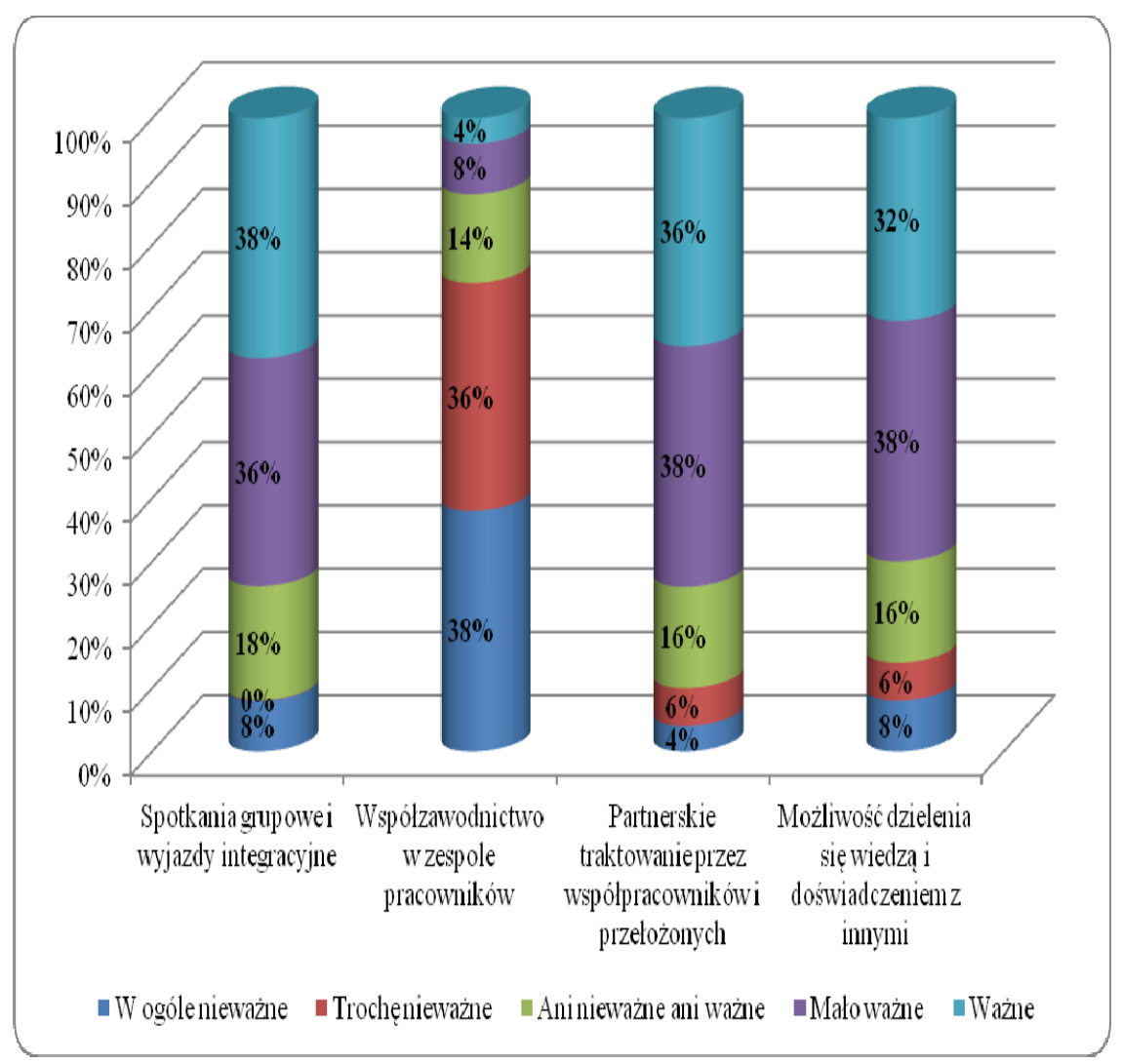

Rysunek 5. Ocena ważności wybranych czynników w pracy.

Źródło: Stec A., Wybrane elementy zarządzania kapitałem ludzkim na przykładzie Tesco, praca magisterska napisana pod kierunkiem dr inż. Jacka Dziwulskiego, Politechnika Lubelska, Wydział Zarzadzania, Lublin 2017.

Odnosząc się do spotkań grupowych i wyjazdów integracyjnych w kontekście ważności w pracy należy wskazać, że zdaniem $38 \%$ badanych czynnik ten jest ważny w pracy. W opinii $36 \%$ respondentów spotkania grupowe i wyjazdy integracyjne są mało ważne w pracy, a dla $18 \%$ ani nieważne ani ważne. Dodatkowo dla $8 \%$ czynnik ten jest w ogóle nieważny w pracy. Ciekawie prezentują się uzyskane opinie w zakresie ważności współzawodnictwa w zespole pracowników. Jedynie dla $4 \%$ czynnik ten jest ważny, a dla $8 \%$ mało ważny w pra- 
cy. Ponadto dla 14\% ankietowanych współzawodnictwo w zespole pracowników nie jest ani nieważne ani ważne, dla 36\% - trochę nieważne, a dla 38\% badanych w ogóle nieważne. Partnerskie traktowanie przez współpracowników i przełożonych jest ważne dla $36 \%$ badanych, a mało ważne dla $38 \%$ z nich. Jednocześnie ani nieważne ani ważne partnerskie traktowanie przez współpracowników i przełożonych jest dla 16\% ankietowanych. Dodatkowo czynnik ten jest trochę nieważny dla $6 \%$ badanych, a w ogóle nieważny dla $4 \%$ z nich. Możliwość dzielenia się wiedzą i doświadczeniem z innymi jest ważna dla $32 \%$ respondentów, a mało ważna dla $38 \%$ z nich. Ani nieważna ani ważna możliwość dzielenia się wiedzą i doświadczeniem z innymi jest dla 16\% badanych. Ponadto dla $6 \%$ badanych czynnik ten jest trochę nieważny, a dla $8 \% \mathrm{z}$ nich w ogóle nieważny.

Największą grupę pośród ankietowanych stanowią osoby, które często dzielą się posiadaną wiedzą oraz doświadczeniem. Grupa ta obejmuje 38\% badanych. Ani rzadko ani często posiadaną wiedzą oraz doświadczeniem dzieli się $36 \%$ respondentów. Ponadto zawsze wiedza i doświadczeniem dzieli się $8 \%$ badanych. Podobny rozkład odpowiedzi odnotowano w przypadku rzadkiego dzielenia się wiedzą i doświadczeniem. Dopełnieniem powyższych informacji jest fakt, że co dziesiąty badany nigdy nie dzieli się posiadaną wiedzą oraz doświadczeniem.

W kontekście posiadanej wiedzy oraz doświadczenia istotnym wydaje się określenie stopnia wykorzystania wiedzy i doświadczenia w pracy. Dane w tym zakresie prezentuje rysunek 6 .

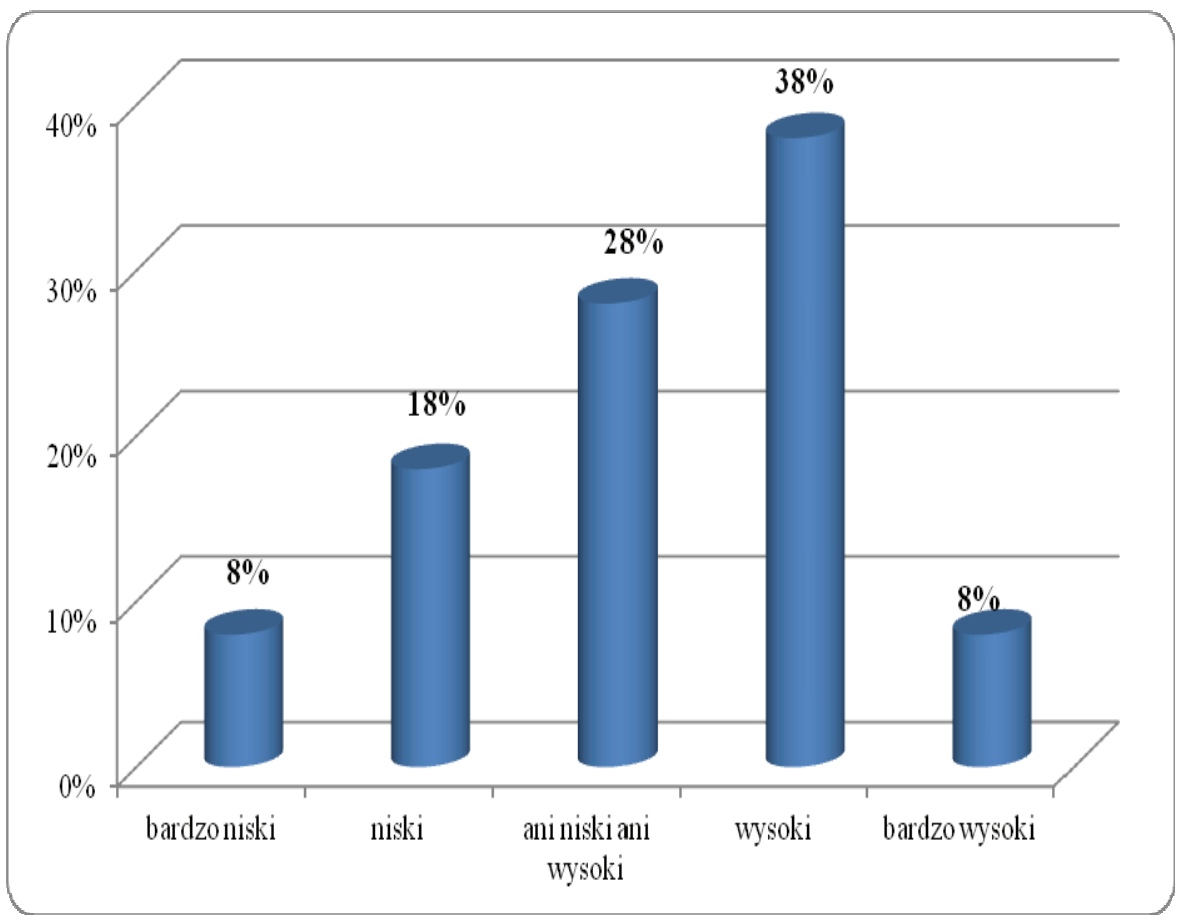

Rysunek 6. Stopień wykorzystania wiedzy i doświadczenia w pracy.

Źródło: Stec A., Wybrane elementy zarzq̨dzania kapitałem ludzkim na przykładzie Tesco, praca magisterska napisana pod kierunkiem dr inż. Jacka Dziwulskiego, Politechnika Lubelska, Wydział Zarzadzania, Lublin 2017. 
Największą grupę pośród badanych stanowią osoby wykorzystują w wysokim stopniu posiadaną wiedzę oraz doświadczenie w pracy. Grupa ta obejmuje 38\% respondentów. W stopniu bardzo wysokim posiadaną wiedzę oraz doświadczenie w pracy wykorzystuje $8 \%$ ankietowanych. Dodatkowo wskazać należy, że ani w stopniu wysokim ani niskim posiadanej wiedzy oraz doświadczenia w pracy nie wykorzystuje $28 \%$ badanych. Jednocześnie dopełnieniem powyższego jest informacja, że w stopniu niskim posiadaną wiedzę oraz doświadczenie w pracy wykorzystuje $18 \%$ badanych, a w stopniu bardzo niskim $-8 \%$ ankietowanych.

\section{Wnioski}

Zarządzanie kapitałem ludzkim stanowi istotne wyzwanie z punktu widzenia funkcjonowania całej organizacji, przede wszystkim aspekcie poziomu wiedzy pracowników. Staje się on wówczas strategicznym zasobem przedsiębiorstwa, bez którego sprawnego i efektywnego wykorzystania niemożliwe będzie osiągnięcie założonych celów strategicznych.

Z przeprowadzonych badań płyną następujące wnioski:

- Odnosząc się do spotkań grupowych i wyjazdów integracyjnych w kontekście ważności w pracy należy wskazać, że zdaniem 38\% badanych czynnik ten jest ważny w pracy. W opinii $36 \%$ respondentów spotkania grupowe i wyjazdy integracyjne są mało ważne w pracy, a dla 18\% ani nieważne ani ważne. Dodatkowo dla 8\% czynnik ten jest w ogóle nieważny w pracy. Ciekawie prezentują się uzyskane opinie w zakresie ważności współzawodnictwa w zespole pracowników. Jedynie dla 4\% czynnik ten jest ważny, a dla $8 \%$ mało ważny w pracy. Ponadto dla 14\% ankietowanych współzawodnictwo w zespole pracowników nie jest ani nieważne ani ważne, dla 36\% - trochę nieważne, a dla 38\% badanych w ogóle nieważne. Partnerskie traktowanie przez współpracowników i przełożonych jest ważne dla $36 \%$ badanych, a mało ważne dla $38 \%$ z nich. Jednocześnie ani nieważne ani ważne partnerskie traktowanie przez współpracowników i przełożonych jest dla $16 \%$ ankietowanych. Dodatkowo czynnik ten jest trochę nieważny dla $6 \%$ badanych, a w ogóle nieważny dla $4 \% \mathrm{z}$ nich. Możliwość dzielenia się wiedzą i doświadczeniem z innymi jest ważna dla 32\% respondentów, a mało ważna dla $38 \%$ z nich. Ani nieważna ani ważna możliwość dzielenia się wiedzą i doświadczeniem z innymi jest dla 16\% badanych. Ponadto dla $6 \%$ badanych czynnik ten jest trochę nieważny, a dla $8 \%$ z nich w ogóle nieważny.

- $\quad 38 \%$ badanych często bierze udział w szkoleniach organizowanych przez Tesco Polska dla pracowników. Ponadto zawsze w szkoleniach udział bierze 4\% ankietowanych. Z kolei rzadki udział w szkoleniach jest domeną 32\% respondentów. Nigdy w szkoleniach udziału nie brało $18 \%$ ankietowanych. Ani rzadko ani często w szkoleniach udział bierze $8 \%$ badanych.

- W ocenie $48 \%$ badanych, szkolenia wpływają przede wszystkim na zwiększenie efektywności pracowników. Nieco mniejsza grupa respondentów, bo $26 \%$ jest zdania, że szkolenia umożliwiaja podnoszenie kwalifikacji zawodowych. Ponadto dla $18 \%$ ankietowanych szkolenia oznaczają wzrost zaangażowania pracowników, a dla 8\% - wzrost motywacji pracowników. 
- Prawie połowa badanych (44\%) spodziewa się po udziale w szkoleniu awansu. Dla 22\% ankietowanych udział w szkoleniach związany jest ze spodziewanym zwiększeniem kompetencji niezbędnych na zajmowanym stanowisku, a dla $18 \% \mathrm{z}$ nich - zaspokojeniem własnych ambicji. Ponadto $16 \%$ respondentów po udziale w szkoleniu spodziewa się zdobycia wiedzy.

- Dla 54\% badanych najważniejszym elementem szkolenia są kompetencje osoby prowadzącej szkolenie. Ponadto $28 \%$ ankietowanych jest zdania, że program jest najważniejszym elementem szkolenia, a 14\% wskazało na atmosferę. Ponadto 4\% respondentów, że najważniejszym elementem szkoleń jest miejsce przeprowadzenia szkolenia.

- Największą grupę pośród ankietowanych stanowią osoby, które często dzielą się posiadaną wiedzą oraz doświadczeniem. Grupa ta obejmuje 38\% badanych. Ani rzadko ani często posiadaną wiedzą oraz doświadczeniem dzieli się $36 \%$ respondentów. Ponadto zawsze wiedza i doświadczeniem dzieli się $8 \%$ badanych. Podobny rozkład odpowiedzi odnotowano w przypadku rzadkiego dzielenia się wiedzą i doświadczeniem. Dopełnieniem powyższych informacji jest fakt, że co dziesiąty badany nigdy nie dzieli się posiadaną wiedzą oraz doświadczeniem.

- Największą grupe pośród badanych stanowią osoby wykorzystują w wysokim stopniu posiadaną wiedzę oraz doświadczenie w pracy. Grupa ta obejmuje 38\% respondentów. W stopniu bardzo wysokim posiadaną wiedzę oraz doświadczenie w pracy wykorzystuje $8 \%$ ankietowanych.

\section{Literatura}

Brdulak J.J., Zarzqdzanie wiedza a proces innowacji produktu. Budowanie przewagi konkurencyjnej firmy, Szkoła Główna Handlowa, Warszawa 2005.

Drucker P, Społeczeństwo prokapitalistyczne, Wydawnictwo Naukowe PWN, Warszawa 1999.

Forlicz S., Informacja w biznesie, Polskie Wydawnictwo Ekonomiczne, Warszawa 2008.

Galata S., Strategiczne zarzadzanie organizacjami. Wiedza, intuicja, strategie, etyka, Difin, Warszawa 2004.

Grudzewski W.M., Hejduk I.K., Zarzqdzanie wiedzq w przedsiębiorstwach, Difin, Warszawa 2004.

Harasim W., Dziwulski J., Zarzq̨anie twórcze, Wyższa Szkoła Promocji Mediów i Show Businessu, Warszawa 2015.

Jashapara A., Zarzqdzanie wiedzq. Zintegrowane podejście, PWE, Warszawa 2006.

Kłak M., Zarzqdzanie wiedzq we współczesnym przedsiębiorstwie, Wydawnictwo Wyższej Szkoły Ekonomii i Prawa, Kielce 2010.

Mikuła B., Organizacje oparte na wiedzy, Wydawnictwo Akademii Ekonomicznej w Krakowie, Kraków 2006.

Perechuda K., Zarzqdzanie wiedzq w przedsiębiorstwie, Wydawnictwo Naukowe PWN, Warszawa 2005.

Probst G., Raub S., Romhardt K., Zarzqdzanie wiedzq w organizacji, Oficyna Ekonomiczna, Kraków 2002.

Stec A., Wybrane elementy zarzqdzania kapitatem ludzkim na przyktadzie Tesco, praca magisterska napisana pod kierunkiem dr inż. Jacka Dziwulskiego, Politechnika Lubelska, Wydział Zarzadzania, Lublin 2017. 
Tiwana A., Przewodnik po zarzqdzaniu wiedzq. E-biznes i zastosowania CRM, Agencja Wydawnicza Placet, Warszawa 2003.

Żabiński L., Marketing: koncepcje, badania, zarzqdzanie, Akademia Ekonomiczna im. Karola Adamieckiego w Katowicach, Katowice 2002.

Żemigała M., Jakość w systemie zarzqdzania przedsiębiorstwem, Placet, Warszawa 2008.

\section{Summary}

The article presents selected concepts of defining and structuring knowledge. The components of human capital most important for the area of knowledge management have been identified. The most important elements of managing organizations in the future were indicated, with particular emphasis on intangible assets.

Key words: knowledge worker, human capital management, service organization.

Informacje o autorze:

dr inż. Jacek Dziwulski

Politechnika Lubelska

Wydział Zarządzania,

Katedra Strategii i Projektowania Biznesu

e-mail: j.dziwulski@pollub.pl 